\title{
Study of the Effect of Burning on the Organic Matter, the Total N, the Total P and the Exchangeable K of the Soils along Northern-East District of Libya
}

\author{
Eldiabani $\mathbf{G S}^{1 *}$, Hale $\mathbf{W H G}^{2}$ and Heron $\mathbf{C P}^{2}$ \\ ${ }^{1}$ Department of Chemistry, Faculty of Art and Science, University of Omer Al Mukhtar, Darna, Libya \\ ${ }^{2}$ Department of Archaeological and Forensic Sciences, University of Bradford, Bradford, UK
}

"Corresponding author: Eldiabani GS, Department of Chemistry, Faculty of Art and Science, University of Omer Al Mukhtar, Darna, Libya, Tel: +218 91934 8098; Email: gibrel.eldiabani@omu.edu.ly

Received date: May 14, 2018; Accepted date: May 21, 2018; Published date: May 25, 2018

Copyright: (c) 2018 Eldiabani GS, et al. This is an open-access article distributed under the terms of the Creative Commons Attribution License, which permits unrestricted use, distribution, and reproduction in any medium, provided the original author and source are credited.

\begin{abstract}
Burning of the soils as a result of the burning of vegetation especially the forests are often due to human activities. Most zones which are affected with burning are arid and semi-arid regions. Libya is one of arid regions in the world because the annual rainfall does not exceed $650 \mathrm{~mm}$ per year except in a small area called Green mountain (Aljabal Alakhdar), which is receive an annual rainfall exceed than $400 \mathrm{~mm}$. It is the only wet area in Libya, so it contains forest with plant diversity. This region (the area covered by this study), like any forest area in the Mediterranean region is exposed to encroachments such as burning parts of it to convert trees to charcoal or burning trees and turning them into agricultural land in other parts. Therefore, the aim of this study was to evaluate the effects of burning on the organic matter, chemical macro nutrients: total nitrogen, total phosphorus and exchangeable potassium that following burning in two areas in the Green Mountain, with those exposed to burning compared to those in adjacent unburned areas in one seaboard (Ras alhelal) and one mountainous (Marawah) site.

The results of this study indicated that the soils in both sites, regardless of burning or depth fall into the silt loam category texture and the main separated particle size was the silt with low clay contents, also the results indicated that, the fire was not enough to change this texture.

In the light of the results obtained, it is clear that soils of both study sites are characterized by low organic matter content. In addition, the results indicate that the average percentage of the organic matter in all layers at the seaboard site was higher than its average percentage in the equivalent layers at the mountainous site. According to the findings obtained from this study, there has been a strong impact of fire on total $\mathrm{N}$ especially in the new burnt (mountainous) site, which agrees reasonably well with the degrees of soil organic matter of both burned study sites. The expected way that total $\mathrm{N}$ would be lost in these soils by fire is in volatilization and particulate transfer to the atmosphere during burning. The results of total $P$ in soils showed that there was more total $P$ in the upper soil layer in the old-burnt site (seaboard) than the new-burnt (mountainous) site at the same depth. It should be noticed from the data that the amount of total $P$ in the seaboard site was high compared with its amount in the mountainous site. As well the results showed that, exchangeable potassium was very limited probably due to its absence in the parent material of the soils and almost all that there is being absorbed by plants. The results indicate that the highest quantities of the exchangeable potassium were in the uppermost layers in both study sites, were particularly high in the mountainous site compared with the seaboard site and were markedly affected by burning in the top layer of the soil.
\end{abstract}

Keywords: Green mountain; Ras alhelal; Marawah burning effect; Organic matter; Total N; Total P; Exchangeable $\mathrm{K}^{+}$

\section{Introduction}

The effect of fires on the nitrogen cycle in soils was clearly described by Neil et al. [1]. They described the transformation of nitrogen under the effect of fires as occurring in several accelerated loss steps. They reported that between $400^{\circ} \mathrm{C}$ and $500^{\circ} \mathrm{C}$ volatilization caused $75 \%$ to $100 \%$ of nitrogen to be lost; between $300^{\circ} \mathrm{C}$ and $400^{\circ} \mathrm{C}, 50 \%$ to $75 \%$ is lost; from $200^{\circ} \mathrm{C}$ to $300^{\circ} \mathrm{C}$, up to $50 \%$ of nitrogen is lost; and below $200^{\circ} \mathrm{C}$ only small amounts of nitrogen are lost. Also, they reported that the ash is formed by combustion of living and dead plant material litter is often removed by wind and contains small amounts of nitrogen but has increased amounts of cations that were present in the fuels before burning. The other step is leaching, which is the transport of $\mathrm{NO}_{3}{ }^{-}$which is less easily attached to soil particles, downward through the soil profile to below the root zone. Post-fire, more $\mathrm{NO}_{3}{ }^{-}$is available to be leached because of absence of uptake by vegetation. The problem is complicated by surface erosion, when the removal of $\mathrm{NH}_{4}{ }^{+}$attached to clay particles occurs.

Another cause of nitrogen loss is the effect of fires on the important biological nitrogen transformation processes. Nitrification, which is the oxidation of ammonium $\left(\mathrm{NH}_{4}^{+}\right)$to nitrite $\left(\mathrm{NO}_{2}{ }^{-}\right)$and then to nitrate $\left(\mathrm{NO}_{3}{ }^{-}\right)$by Nitrosomonas bacteria can be affected because these bacteria can be killed in dry soil at $140^{\circ} \mathrm{C}$ and in wet soil at $75^{\circ} \mathrm{C}$. Nitrobacter bacteria are more sensitive and are killed at $100^{\circ} \mathrm{C}$ in dry and $50^{\circ} \mathrm{C}$ in wet soil. Mineralization, which is a conversion of organic $\mathrm{N}$ to the ammonium form through decomposition, is also accelerated 
by fire. Losses may also occur by immobilization and biological fixation of nitrogen [1,2]. DeBell and Ralston [3] pointed out that during pyrolysis, organic nitrogen (mainly amino acids in plant material and litter) is converted to volatile, gaseous forms of $\mathrm{NH}_{4}^{+}$ (ammonia), molecular $\mathrm{N}$, and various oxides of nitrogen. They found that $62 \%$ of the nitrogen content of pine needles and litter was lost during combustion, mostly as gaseous nitrogen, and concluded that the loss of nitrogen is partially compensated by the increased availability of the nitrogen that remains after the fire. On the other hand, Christensen [4] found in his study in Californian chaparral (USA) that soluble forms of nitrogen, ammonium $\left(\mathrm{NH}_{4}{ }^{+}\right)$, and nitrate $\left(\mathrm{NO}_{3}{ }^{-}\right)$were higher in burned soil than in unburned soil, and Christensen and Muller [5] suggested that increases in $\left(\mathrm{NO}_{3}{ }^{-}\right)$after fire are due to mineralization and nitrification. Also, Prieto-Fernandez et al. [6] found that exchangeable $\mathrm{NH}_{4}{ }^{+}$can increase during fire. In a ponderosa pine forest, the same results were found by Choromanska and DeLuca [7]. They found that $\mathrm{NH}_{4}{ }^{+}$concentrations remained higher than did the unburned control for a year, with initial post-fire concentrations of $\mathrm{NH}_{4}{ }^{+}$for wildfire of $19.5 \mu \mathrm{g} \mathrm{g}{ }^{1}$ as compared to the unburned control of $1.9 \mu \mathrm{g} \mathrm{g}^{-1}$. They reported exchangeable $\mathrm{NH}_{4}{ }^{+}$may originate from the thermal decomposition at $200^{\circ} \mathrm{C}$ of organic matter amino acids.

Fire can cause the release of inorganic phosphorus from soil organic matter. However, a fire's effect on soil phosphorus availability is likely to be complex. Availability could be decreased by adsorption to newly exposed or newly created $\mathrm{Fe}$ and $\mathrm{Al}$ hydrous oxide surfaces or precipitation with calcium. Conversely, phosphorus availability can be increased by degradation and partial combustion of soil organic matter and by increases in $\mathrm{pH}$, causing desorption from $\mathrm{Fe}$ and $\mathrm{Al}$ hydrous oxides surfaces [8]. Many studies have explored the change in phosphorus content of soil pre- and post- fires. DeBano and Klopatek [9] reported that significant increases in $\mathrm{NaHCO}_{3}{ }^{-} \mathrm{P}$ (total bicarbonateextractable phosphorus) lasted only 45 days following burning, and Adams et al. [10] noted that it is common for fire-induced extractable$\mathrm{P}$ increases to decline to pre-burn levels within 1 year.

Other studies have examined the effects of fire on soil phosphorus contents at different soil depths. Wells in 1971 conducted a study on the effects of wildfire on phosphorus content of forest soils and found significant increases in extractable phosphorus in the $0-10 \mathrm{~cm}$ layers of a coastal plains pine system after 20 years of annual burning. DeRonde [11] also found that a high intensity wildfire resulted in an immediate increase in phosphorus levels from the $0-5 \mathrm{~cm}$ layer of a Pinus pinaster forest in the southern cape forest region of south Africa. However, Murphy et al. [8] found in their study that no firm conclusions could be made about the short-term effects of fire on phosphorus availability. Stephens et al. [12] found that fires released calcium and raised soil $\mathrm{pH}$ and may have resulted in the incorporation of phosphorus into insoluble forms.

Blank et al. [13] studied the effects of the fire on soil solution ortho$\mathrm{P}$ and suggested that available phosphorus was higher in the early stages after the fire. However cumulative phosphorus leaching as measured by resin lysimeters, was not significantly affected by the fire, and they concluded that no firm conclusions could be determined regarding the short-term effects of fire on phosphorus availability.

The majority of phosphorus is lost during volatilization of the litter and biomass. Fire temperatures above $300^{\circ} \mathrm{C}$ increase the volatilization losses of organic phosphorus, whereas water-soluble, available phosphorus increased after burning [14]. They also reported that, as soil organic phosphorus is thermally mineralized, available phosphorus increases with increases in temperature. Furthermore, Overby and Perry [15] found that volatilized phosphorus from the litter and surface organic matter can be translocated down the soil profile along a decreasing temperature gradient, subsequently condensing on the intervening soil particles.

This study describes the potential impacts of fire on the plant nutrients available, especially nitrogen and phosphorus, since their loss over a substantial period could seriously affect the recovery of vegetation after a fire.

Khanna and Raison [16] noted that fire caused an increase of exchangeable $\mathrm{K}^{+}$at a burnt site, but not $\mathrm{Na}^{+}, \mathrm{Ca}^{+2}$, or $\mathrm{Mg}^{+2}$. In addition, they reported that incomplete combustion of organic matter by low intensity fire could have partly accounted for the insignificant release that they recorded of cations to the soil. However, Litton and Santelices [17] found that potassium appears to decrease in concentration with time after a fire, DeRonde [11] reported significantly higher levels of exchangeable potassium in burned forests for a period of 21 months following a wildfire. In contrast, Murphy et al. [8] found in their study that there were no consistent or significant effects on potassium content in soil after fire.

\section{Methodology}

\section{Study area, site selection and sample collection}

This study was conducted in the Aljabal Alakhdar (green mountain) region, Libya (Figure 1). The climate in the study area is semi-arid, being hot and dry in the summer, warm and wet in the winter. Most of the precipitation falls during the period from October to April at an annual rate of between $275-660 \mathrm{~mm}$. The annual minimum and maximum temperatures are approximately 10 and $35^{\circ} \mathrm{C}$, annually [18].

Two sites have been used in this study. The first one is in area called Ras Alhelal subsequently; this site will be referred to as the seaboard site. It is located between the longitudes $22^{\circ} 12^{\prime} 030^{\prime \prime}$ and $22^{\circ} 13^{\prime} 120^{\prime \prime}$, and the latitude $32^{\circ} 52^{\prime} 390^{\prime \prime}$ and $32^{\circ} 53^{\prime} 132^{\prime \prime}$ at an altitude of $83 \mathrm{~m}$ above sea level, approximately $1.5 \mathrm{~km}$ away from the seashore The area is commonly occupied by forests, which consist of species such as Juniperus phoenicia, Pinus halepensis, Arbutus pavarii, Ceratonia siliqua, Olea europea var. eleaster, and bushes such as Pistacia lentiscus, Phlomis floccosa, Rosmarinua officinalis, Cistus sps., Marrubium vulgare, and Phillyrea angustifolia. The forest has existed for at least 200 years [19]. According to (USDA, 2001) the soils in the area are classified as Lithic Hapeloxeralf. In the year 2010, fires affected the forests of this region destroying the vegetation in more than 22 hectares out of the total of about 120 hectares [20].

The second site is located in an area called Marawah, approximately $150 \mathrm{~km}$ South-West of the first site. Throughout the rest of this study it will be referred to as the mountainous site. It is located between longitude $21^{\circ} 24^{\prime} 021^{\prime \prime}$ and $21^{\circ} 25^{\prime} 299^{\prime \prime}$ and latitude $32^{\circ} 29^{\prime} 038^{\prime \prime}$ and $32^{\circ} 29^{\prime} 464^{\prime \prime}$, at an altitude of $540 \mathrm{~m}$ above sea level, and about $2 \mathrm{~km}$ east of Marawah village (Figure 1). This site is one of ancient woodlands which consist mostly of Aleppo trees (Pinus halepensis). These woodlands have been grazed for more than 40 years. According to the American soil classification system (USDA, 2001), the soils in this site are classified as Typic Haploanthrepts. In July 2013 fires swept through about 11 hectares of this site.

These sites occur in the same region (Aljabal Alakhdar) and in convergent climatic conditions, however they lie in different 
Citation: Eldiabani GS, Hale WHG, Heron CP (2018) Study of the Effect of Burning on the Organic Matter, the Total N, the Total P and the Exchangeable K of the Soils along Northern-East District of Libya. J Environ Anal Chem 5: 242. doi:10.4172/2380-2391.1000242

Page 3 of 7

geographical units (seaboard and mountainous) and have a different vegetation density.

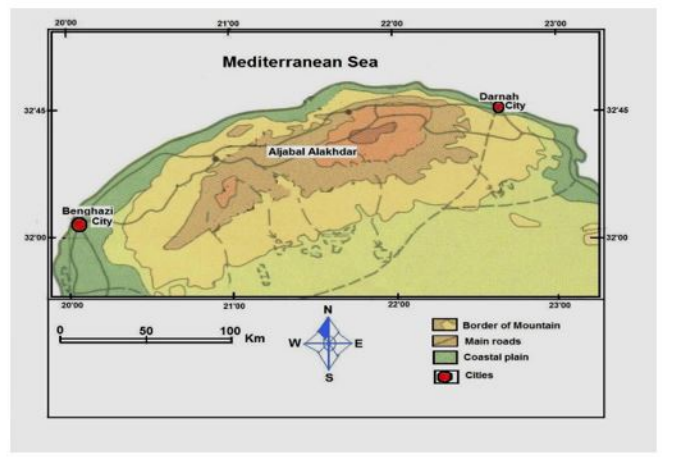

Figure 1: Map of the study area (Aljabal Alakhdar) (Source: Libyan National Atlas, 1980).

\section{Soil sample collection}

At each of the two sites sampled (seaboard and mountainous), two areas (burned and unburned) were studied. According to the soil profile description in the two sites, which were consistent in their soil characterizations for burned and unburned areas, the soil samples from the seaboard site in the burned and unburned areas were collected from following horizons that were identified in the field, i.e., from the centre of the following layers: $0-15,15-35$, and $35-60 \mathrm{~cm}$ depth. Samples from the second site (mountainous) in the burned and unburned areas were taken from the centre of the horizons: 0-15, 15-45, and 45-70 cm depth. The sampling protocol followed for both sites, both burned and unburned areas, was as shown in Hemingway [21]. In the two sites (seaboard and mountainous) the protocol was involved collecting the samples from nine positions in the form of a zigzag line to cover the studied area as much as possible, in the circumstances of this study the distance between each point was about 18 meters in the coastal site and about $22 \mathrm{~m}$ in the mountainous site. To avoid the mixture of the samples with each other, the third depth was collected first, then the second and finally the first depth. This means there were three soil samples at each of nine positions per area for burned and unburned area at each site (seaboard and mountainous). All samples at the four study areas were collected by auger tool which was marked at the required depths. A total of fiftyfour soil samples were therefore collected from each site (3 depths $\times 9$ replicates $\times 2$ areas), and the total number of samples for both sites was 108. These samples were manually broken down and air-dried for not less than 72 hours. The samples were then disaggregated by mortar, passed through a $2 \mathrm{~mm}$ sieve and placed in labeled sample plastic bags.

\section{Method of soil analysis}

Soil particle size analysis: Has been estimated using the pipettesedimentation method [22].

Soil organic matter: The soil organic matter was determined gravimetrically by using the loss on ignition method.

Total nitrogen: Was determined by the semi-micro Kjeldahl method [23].
Total phosphorus: Was measured using the procedure described by Bethell and máté [24].

Exchangeable potassium: Exchangeable $\mathrm{K}^{+}$was estimated by soil$\mathrm{NH}_{4} \mathrm{C}_{2} \mathrm{H}_{3} \mathrm{O}_{2}$ extract [25].

\section{Statistical analysis}

A 3-factor analysis of variance test with replications was undertaken in order to statistically verify the results of this study. The factors used related to sample values obtained from the site (seaboard and mountainous), the soil type (burned and unburned) and the depth $(0-15,0-35,35-60 \mathrm{~cm}$ for the coastal site and $0-15,15-45,45-70 \mathrm{~cm}$ for the mountain site). MINITAB Release 17 Statistical Software has been used for Windows on CD-ROM, 2016 edition for all data analysis, both statistical and graphical.

\section{Results and Discussion}

\section{Soil particle size}

From field observation of the soil profiles of both study sites indicated that these profiles were characterized by a granular structure in the surface layers and sub-angular soil structures in the sub-surface layer horizons (Table 1).

\begin{tabular}{|c|c|c|c|c|c|}
\hline \multirow[b]{2}{*}{ Site } & \multirow{2}{*}{$\begin{array}{l}\text { Soil depth } \\
(\mathrm{cm})\end{array}$} & \multirow{2}{*}{$\begin{array}{l}\text { Sample } \\
\text { area }\end{array}$} & \multicolumn{3}{|c|}{$\begin{array}{l}\text { Percentage of soil particles } \\
\text { within each size fraction }\end{array}$} \\
\hline & & & Clay & Silt & Sand \\
\hline \multirow[b]{6}{*}{ Seaboard $^{*}$} & \multirow[b]{2}{*}{$0-15$} & burned & ${ }^{a} 21.0^{a}$ & ${ }^{a} 52.0^{a}$ & ${ }^{a} 27.0^{a}$ \\
\hline & & unburned & ${ }^{a} 21.3^{a}$ & a51.4 & ${ }^{a} 27.3^{a}$ \\
\hline & \multirow[b]{2}{*}{$15-35$} & burned & 23. $7^{b}$ & $51.7^{a}$ & $24.6^{b}$ \\
\hline & & unburnrd & $24.2^{\mathrm{b}}$ & $51.2^{\mathrm{a}}$ & $25.0^{\mathrm{b}}$ \\
\hline & \multirow[b]{2}{*}{$35-60$} & burned & $24.0^{\mathrm{b}}$ & $51.0^{\mathrm{a}}$ & $25.0^{c}$ \\
\hline & & unburned & $22.4^{\mathrm{C}}$ & $51.0^{a}$ & $26.6^{c}$ \\
\hline \multirow[b]{6}{*}{ Mountainous* } & \multirow[b]{2}{*}{$0-15$} & burned & ${ }^{a} 8.4^{a}$ & ${ }^{\mathrm{a}} 62.6^{\mathrm{a}}$ & ${ }^{\mathrm{a}} 29.4^{\mathrm{a}}$ \\
\hline & & unburned & ${ }^{\mathrm{a}} 8.2^{\mathrm{a}}$ & ${ }^{\mathrm{a}} 61.8^{\mathrm{a}}$ & a $30.0^{a}$ \\
\hline & \multirow[b]{2}{*}{$15-45$} & burned & $13.2^{b}$ & $61.3^{a}$ & ${ }^{\mathrm{a}} 25.5^{\mathrm{a}}$ \\
\hline & & unburned & $13.5^{\mathrm{b}}$ & $61.0^{\mathrm{a}}$ & ${ }^{a} 25.5^{a}$ \\
\hline & \multirow[b]{2}{*}{$45-70$} & burned & $12.4^{\mathrm{c}}$ & $61.0^{\mathrm{a}}$ & $26.6^{\mathrm{C}}$ \\
\hline & & unburned & $12.0^{\mathrm{C}}$ & $60.0^{a}$ & $28.0^{\mathrm{C}}$ \\
\hline
\end{tabular}

* Symbols means the differences were highly significant $(p<0.001)$ between the two sites in each of the soil particle size analysis results. The litters who are on the upper statistical analysis results between the three studied depths in the two sites of the study area, while those who are on the upper right side of the values represent the statistical analysis results between the burned and unburned depths. Across each column, values followed by a different letter are significantly different $(p<0.001)$ while those followed by a same letter are not significantly different $(p>0.05)$.

Table 1: Results of soil particle size analysis in the two study sites (seaboard and mountainous), for both burned and unburned areas at three depths. Each value represents the average of 9 replicates. 
Results from Table 1 indicated that silt represented the main component of the mineral parts of the soils sampled at both study sites in both burned and unburned areas, while the clay (particles of $<2 \mu \mathrm{m}$ in diameter) content was always the smallest fraction compared to the contents of silt (particles of $2 \mu \mathrm{m}-50 \mu \mathrm{m}$ in diameter) and sand (particles of 50-2000 $\mu$ min diameter), especially in mountain sites, but increased with depth. Particle size analysis also showed that sand sized particles form between 24.6 and $30 \%$ of the mineral part of the sampled soils.

These results confirmed by the ANOVA results which indicated that the differences were highly significant $(\mathrm{p}<0.001)$ between the study sites in the clay, silt and sand contents, however the differences were highly significant between different depths in clay content (Table 1).

The fact that there were relatively high proportions of silt and sand and a low content of clay in the mountain sites as compared to the coastal site may be due to the lower density of vegetation at the mountain site. The reduced quantity of vegetation may have affected the erosion of soil and therefore the selective movement of the clay particles, leaving the large particles of sand and silt in situ [20]. This explanation has been advanced elsewhere in many studies [26,27]. Also, the results indicated that all the soils (for both areas and all depths) fall into the category of a silt loam [28].

\section{Organic matter (OM)}

Soils of both study sites are characterized by low organic matter content (Table 2).

\begin{tabular}{|c|c|c|c|c|c|c|}
\hline Site & $\begin{array}{l}\text { Soil } \\
\text { depth } \\
(\mathrm{cm})\end{array}$ & $\begin{array}{c}\text { Sample } \\
\text { area }\end{array}$ & $\begin{array}{l}\text { OM } \\
(\%)\end{array}$ & $\begin{array}{l}\text { TN } \\
(\%)\end{array}$ & $\begin{array}{c}\text { TP } \\
\text { (ppm) }\end{array}$ & $\begin{array}{l}\text { Exchangeab } \\
\text { le } \mathrm{K}^{+} \text {(meq. } \\
\left.100 \mathrm{~g} \mathrm{soil}^{-1}\right)\end{array}$ \\
\hline \multirow[t]{6}{*}{ Seaboard $^{*}$} & \multirow[t]{2}{*}{$0-15$} & burned & ${ }^{\mathrm{a}} 2.42^{\mathrm{a}}$ & $\begin{array}{c}a 0.35 \\
a\end{array}$ & $\mathrm{a}_{19.02^{\mathrm{a}}}$ & $\mathrm{a}_{1} .06^{\mathrm{a}}$ \\
\hline & & unburned & ${ }^{a} 2.53^{a}$ & $\begin{array}{c}a 0.66 \\
\mathrm{a}\end{array}$ & ${ }^{a} 21.03^{a}$ & ${ }^{a} 1.92^{a}$ \\
\hline & \multirow[t]{2}{*}{$15-35$} & burned & $1.51^{\mathrm{b}}$ & $0.26^{b}$ & $5.42^{\mathrm{b}}$ & $0.31^{b}$ \\
\hline & & unburnrd & $1.46^{\mathrm{b}}$ & $0.22^{b}$ & $5.84^{b}$ & $0.23^{b}$ \\
\hline & \multirow[t]{2}{*}{$35-60$} & burned & $1.43^{b}$ & $0.08^{b}$ & $6.36^{c}$ & $0.38^{\mathrm{c}}$ \\
\hline & & unburned & $1.40^{\mathrm{C}}$ & $0.13^{c}$ & $6.38^{\mathrm{c}}$ & $0.38^{\mathrm{c}}$ \\
\hline \multirow[t]{6}{*}{ Mountainous* } & \multirow[t]{2}{*}{$0-15$} & burned & $\mathrm{a}_{1} .07^{\mathrm{a}}$ & $\begin{array}{c}a 0.14 \\
a\end{array}$ & $\mathrm{a}_{1.39^{a}}$ & ${ }^{a} 1.92^{a}$ \\
\hline & & unburned & $\mathrm{a}_{1.65^{\mathrm{a}}}$ & $\begin{array}{c}a 0.60 \\
a\end{array}$ & $\mathrm{a} 16.48^{\mathrm{a}}$ & ${ }^{\mathrm{a}} 0.83^{\mathrm{a}}$ \\
\hline & \multirow[t]{2}{*}{$15-45$} & burned & $1.12^{\mathrm{b}}$ & $0.10^{b}$ & $\mathrm{a}_{2.45^{\mathrm{a}}}$ & $0.62^{\mathrm{b}}$ \\
\hline & & unburned & $1.15^{\mathrm{b}}$ & $0.15^{b}$ & ${ }^{\mathrm{a}} 2.57^{\mathrm{a}}$ & $0.42^{\mathrm{b}}$ \\
\hline & \multirow[t]{2}{*}{$45-70$} & burned & $1.02^{\mathrm{C}}$ & $0.07^{c}$ & $2.37^{c}$ & $0.85^{\mathrm{C}}$ \\
\hline & & unburned & $1.08^{\mathrm{c}}$ & $0.06^{c}$ & $2.13^{c}$ & $0.60^{c}$ \\
\hline
\end{tabular}

* Symbols means the differences were highly significant $(p<0.001)$ between the two sites in each of the soil particle size analysis results. The litters who are on the upper statistical analysis results between the three studied depths in the two sites of the study area, while those who are on the upper right side of the values represent the statistical analysis results between the burned and unburned depths. Across each column, values followed by a different letter are significantly different $(p<0.001)$ while those followed by a same letter are not significantly different $(p>0.05)$.

Table 2: Results of soil organic matter (OM), total N (TN) and total P (TP) analysis in the two study sites (seaboard and mountainous), for both burned and unburned areas at three depths. Each value represents the average of 9 replicates.

In addition, the results indicate that the average percentage of the organic matter in all layers at the seaboard site was higher than its average percentage in the equivalent layers at the mountain site. This may be due to the diversity of vegetation in the coastal site, as this site included several species of trees, bushes, etc., while in the mountainous site, the forest included just one type of tree. The two sites are statistically significantly different $(\mathrm{p}<0.001)$ from each other in the amount of organic matter percent (Table 2). Furthermore, the illustrated surface plots in Figure $2 \mathrm{~A}$ show that the organic matter percentages decreased with depth in the seaboard site and in the unburned mountainous area; the low content of organic matter in the burned uppermost layer in the mountainous site may emphasize the effect of fire on this layer (Figure 2B). Decreasing organic matter with depth was expected, due to the accumulation and degradation of the plant residues in the top layers and the microbial activities of degradation of organic matter decrease with depth. Results of the ANOVA also indicated that there were highly significant differences $(\mathrm{p}<0.001)$ between the different depths.

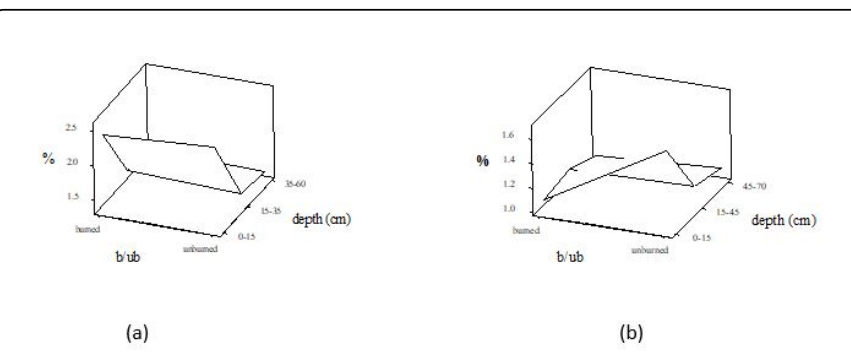

Figure 2: Surface plot showing the variation in organic matter (\%) at three depths in burned (b) and unburned (ub) soils from (A) the seaboard site and (B) the mountainous site.

Although the statistical differences for the effect of burning on the organic matter were highly significant, this was most marked in the mountainous site. This may be because the seaboard site as an oldburned site seems to have started on the recovery processes and the cycling of the organic matter decomposition at this ecosystem has begun; while in the mountainous site, the period of burning has been more recent, and fire has had the effect of decreasing the organic matter. This was noted by its low value in the uppermost burned layer compared with the same layer depth in the unburned area. It is notable that all the interaction terms are also significant $(\mathrm{p}<0.001)$, particularly because of the pronounced effect of burning on the top soil layer associated with the fact that this effect is different when comparing the burned to the unburned areas in the mountainous site than it is in the seaboard site.

These results are consistent with those found in this study. For example, Fernadez et al. [29] noticed in their study in a Humic Cambisol under pine forest, Spain, after a fire that organic carbon suffered losses higher than $50 \%$ in the upper $10 \mathrm{~cm}$ of studied soil profiles. On the other hand, while Hungerford et al. [30] noticed in 
their study that organic matter was destructively distilled between 200 and $300^{\circ} \mathrm{C}$, Almendros et al. [31] reported that it is difficult to generalize the percent loss of soil organic matter from a single burn without knowledge of the fire intensity and antecedent conditions.

In contrast, an increase of organic matter content after burning has also been reported by several studies. Choonsig Kim et al. [32] found in their short time change (one week after fire) study in Pinus densiflora forests, Korea that organic matter content at the $0-5 \mathrm{~cm}$ depth was slightly higher in the burned area. They attributed that to ash mixed into the top mineral soil arising from the burning. However, Lee et al. [33] gave the reason for an increase in the organic matter in surface layers after fire to be due to much dead root biomass.

\section{Total nitrogen (TN)}

According to the findings contained in Table 2, the pattern of distribution of average amounts of total $\mathrm{N}$ is similar to the pattern of distribution of organic matter. Thus, the results have showed a marked decrease of its concentration values with depth (Figure 3), particularly in the unburned areas. Results also indicate the average values of total $\mathrm{N}$ in the seaboard site are higher than its average values in the mountainous site (Figure 3A and 3B). A period of 8 years after a forest fire in the seaboard site appears to have restored the pre-fire level of total nitrogen, this may be attributed to the growth of plant colonists after fire disturbances and to the increase in soil temperature and moisture resulting from the removal of dominant vegetation which can enhance microbial activity which, in turn, may lead to an increased rate of mineralization of nitrogen. This phenomenon continues until the increased nutrients are taken up by new plants, are immobilized by microbes or are used up in chemical reactions [2]. Similar findings have been recorded by Wells in 1979 namely that the replacement of $\mathrm{TN}$ to pre-fire levels occurred within a few years.

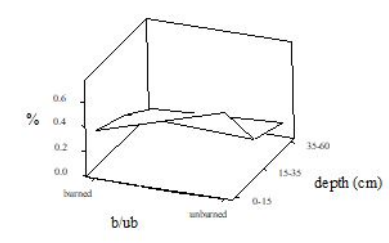

(a)

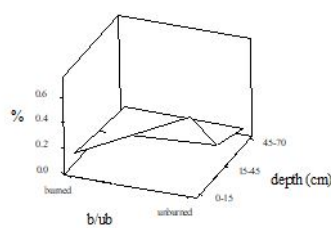

(b)
Figure 3: Surface plot showing the variation in total nitrogen (\%) at three depths in burned (b) and unburned (ub) soils from (A) the seaboard site and (B) the mountainous site.

May due to this, statistical analysis of the three-factor ANOVA results for this study confirmed that, there were highly significant differences $(\mathrm{p}<0.001)$ in the content of total $\mathrm{N}$ between the different depths, between the studied sites and as a result of fire, with average values of total $\mathrm{N}$ in the burned areas in both sites at the uppermost layer being less than its average values in the unburned areas, especially in the mountain sites (Table 2).

These results are consistent with the effect of fire contributing to the loss of nitrogen by volatilization and particulate transfer to the atmosphere, especially in the site of the most recent fire [34,35]. All the interaction terms involving burning were statistically highly significant $(\mathrm{p}<0.001)$ because of this; and the interaction between depth and site was very significant too $(p<0.001)$ because of the different rates of decline in total $\mathrm{N}$ with depth in the two sites.

Generally, the losses of TN by fire in this study agree with the results of Baird et al. [36] who reported significant TN losses in the A soil horizon one year after fire. However, Dyrness et al. [37] noticed both an increase and a decrease in soil TN following fire in Alaska. Rashid [38] measured increase soil TN five months after fire, but concentrations decreased to near control levels 16 months later.

\section{Total phosphorus (TP)}

It seems clear from the results that the average amounts of total phosphorus (TP) in soils of the study sites behave in a similar manner to those of organic matter and total nitrogen in the mountainous site, but somewhat different responses in the seaboard site (Table 2). In the seaboard site the TP concentration is much higher in the upper soil layer (Figure 4A). This may be attributed to phosphorus being classified as an immobile element in the soil so that it does not move much down the soil profile [39]. The present results indicate that the values of TP in the seaboard (less recently burned) site are higher than their equivalent values in the mountainous site, this is may due to the density of vegetation which is more intensive in the seaboard site (Figure 4B). By contrast, the lowest content of the TP was recorded in the burned uppermost layer at the mountainous site which is considered a recently burned site; possibly the majority of phosphorus is lost by fire during volatilization of the litter and biomass. Statistical analysis by three-factor ANOVA of these results indicates that all three of the main factors were highly significant $(p<0.001)$, as well as all of the interactions because of the different concentrations of the TP in the two sites as a response to burning and to depth (Table 2). Generally, it seems that in spite of loss of large amounts of this element as a result of fire, the concentrations do recover with time as has been observed in the seaboard site.

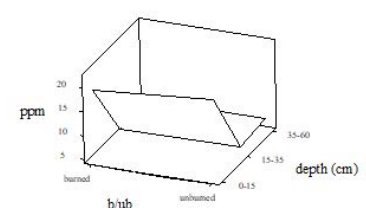

(a)

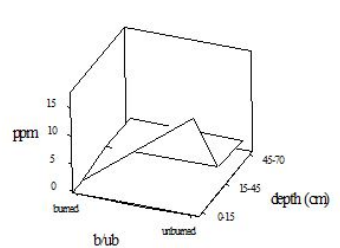

(b)
Figure 4: Surface plot showing the variation in total phosphorus $(\mathrm{ppm})$ at three depths in burned (b) and unburned (ub) soils from (A) the seaboard site and (B) the mountainous site.

DeBano and Conard [40] have suggested that most phosphorus found in the plants and litter is consumed during a fire. They also reported that this consumed phosphorus may return to the soil surface as ash. If this ash is not removed from site by wind and surface runoff, it will be incorporated into the soil matrix, resulting in increased levels of phosphorus following fire over a period of five years or longer.

The loss of TP by fire in this study agrees with the findings of Duguy et al. [41] who observed in an eastern Spanish area that a decrease in soil total phosphorus following fire. Likewise, Wells in 1971 reported significant increases in TP in the $0-10 \mathrm{~cm}$ layer of a coastal plains pine system after 20 years of burning. On the other hand, this study 
contrasts with that of Litton and Santelices [17] who found increases in $\mathrm{TP}$ immediately following fire. They attribute that to the effect of fire in eliminating a large portion of the organic material in the litter, which could speed up the process of oxidation and this can result in readily available nutrients in ash left after a fire has passed.

\section{Exchangeable potassium $\left(\mathrm{K}^{+}\right)$}

Exchangeable potassium represents a very limited ratio of the total exchangeable cations (Table 2). This is probably due to its absence in the parent material of the soils and almost all that there is being absorbed by plants. The results indicate that the highest quantities of the exchangeable potassium were in the uppermost layers in both study sites, were particularly high in the mountainous site compared with the seaboard site and were markedly affected by burning in the top layer of the soil (Figures 5A and 5B). Thus, it was not surprising that the results of the ANOVA statistical analysis results show highly significant differences $(p<0.001)$ between the two studied sites, and between the different depths $(p<0.001)$ with the decrease of its concentration with depth probably being due to the continuous depletion by plant roots because it is one of the main nutrients (Table 2). Furthermore, the ANOVA results also show highly significant differences $(\mathrm{p}<0.001)$ in the average exchangeable potassium concentration between burned and unburned areas, where fire appears to be cause an increase in this exchangeable cation.

Besides the individual factor effect of burning on the exchangeable potassium content, however, all the interaction effects are also highly significant $\mathrm{p}<0.001$; (Table 2 ). The soil exchangeable potassium is most increased in the burned mountainous site in the top soil layer, which is a positive effect. It is known that potassium is a macro-nutrient element of plants and its most important function is to increase the synthesis and transmission of carbohydrates, which promotes increased thickness of cell walls and the strength of plants stems, so its increased availability after burning will encourage plant regrowth [42].

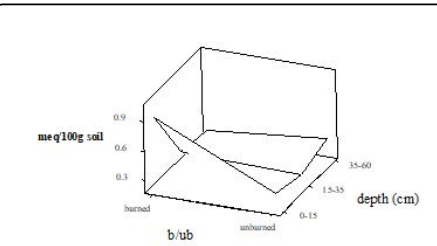

(a)

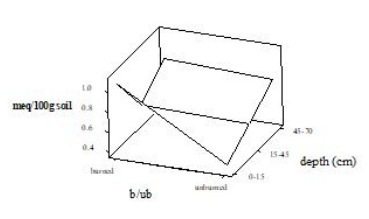

(b)
Figure 5: Surface plot showing the variation in exchangeable $\mathrm{K}^{+}$ (meq. $100 \mathrm{~g} \mathrm{soil}^{-1}$ ) at three depths in burned (b) and unburned (ub) soils from (A) the seaboard site and (B) the mountainous site.

\section{Conclusion}

Although the results of this study for the effect of burning on the soils of this type of ecosystem show agreement with those of some investigations and do not agree with those of some authors, the impact of burning of soil on the studied parameters of this study were very obvious especially in the mountainous site which has been subjected to fire recently.

The results of this study showed that, the soil of the study area sites, whether burned and unburned from the seaboard or mountainous site, and within all horizons were characterized by a silt loam texture which means that the fire was not enough to change the studied soil fractions and therefore the type of texture. Results also indicated that silt represented the main component of the mineral parts of the soils sampled at both study sites in both burned and unburned areas, while the clay content was always the smallest fraction, especially in mountainous sites, but increased with depth. Particle size analysis also showed that sand sized particles form between 24.6 and $30 \%$ of the mineral part of the sampled soils. Also, the results indicated that all the soils (for both areas and all depths) fall into the category of a silt loam.

The data obtained from this study have confirmed that the soils of the study sites are poor in their content of organic matter and significantly higher in the surface layer than the sub-surface layer. This may consistent with the results of this study which indicated that the percentage of clay fraction in the two study sites in both burned and unburned soils was low. The data also showed that fire appeared to decrease soil organic matter of these soils as a result of the pyrolysis of organic materials by heat. When compared against the old burnt site, the fire event of 2010 in the seaboard site accounted for a loss of about $4.38 \%$ soil organic matter in the surface layer, while in the newly burnt site (mountainous site) fire accounted for a loss of about $35 \%$ soil organic matter at the same depth.

On the other hand, the results from this study showed that fire resulted in lower TN, especially in the new-burnt (mountainous) site, which agrees reasonably well with the decrease of soil organic matter of both burned study sites. The expected way that TN would be lost in these soils by fire is in volatilization and particulate transfer to the atmosphere during burning. The data also showed there was a significant difference in TN loss percentages between the seaboard and the mountainous site. These percentages have decreased by about 47 and $77 \%$ for the upper depth layer in the burned area of the seaboard and the mountainous site, respectively, compared to the upper depth layer in the unburned area at the same sites.

The data obtained from this study indicated that, there was more TP in the upper soil layer in the old-burnt (seaboard) site than the newburnt (mountainous) site at the same depth. Less phosphorus in the upper depth of the burned area at the mountainous site may be due to volatilization loss. Moreover, its amount decreased sharply with depth in the studied soils; this is fully consistent with the pattern of distribution of organic matter in the studied soil profiles, as well as the limited leaching characteristics of phosphorus due to its immobility.

Furthermore, although the quantity of exchangeable $\mathrm{K}^{+}$was limited, fire caused an increase in the exchangeable quantity of this cation by about $57 \%$ in the mountainous unburned area. $\mathrm{K}^{+}$is generally absorbed in excess by plants; the element is concentrated in the aboveground biomass and thus in upper layers of the soil. Although this is contradictory to reports of an overall increase of exchangeable $\mathrm{K}$ ${ }^{+}$, these results correspond with those found by DeRonde [11] who reported significantly higher levels of exchangeable $\mathrm{K}^{+1}$ in burned forests for a period of 21 months following fire $[16,43]$.

\section{References}

1. Neil SG, Wagtendonk JWV, Den Daas JH (2006) Fire in California's Ecosystems. Berkeley and Los Angeles, University of California Press, p: 612.

2. Kimmins JP (1996) Importance of soil and role of ecosystem disturbance for sustained productivity of cool temperate and boreal forests. Soil Science Society of America Journal 56: 1643-1654. 
3. DeBell DS, Ralston CW (1970) Release of nitrogen by burning light forest fuels. Soil Science Society of America 34: 936-938.

4. Christensen NL (1973) Fire and the nitrogen cycle in California chaparral. Forest Ecology and Management 181: 66-68.

5. Christensen NL, Muller CH (1975) Effects of fire on factors controlling plant growth in Adenostoma chaparral. Ecological Monographs 45: 29-55.

6. Prieto-Fernandez A, Acea MJ, Carballas T (1998) Soil microbial and extractable $\mathrm{C}$ and $\mathrm{N}$ after wildfire. Biology and Fertility of Soils 27: 132-142.

7. Choromanska U, DeLuca TH (2001) Prescribed fire alters the impact of wildfire on soil biochemical properties in a ponderosa pine forest. Soil Science Society of America Journal 65: 232-238.

8. Murphy JD, Johnson DW, Miller WW, Walker RF, Carrol EF, et al. (2006) Wildfire effects on soil nutrients and leaching in a Tahoe basin watershed, Nevada, USA. Journal of Environmental Quality 35: 479-489.

9. DeBano LF, Klopatek JM (1988) Phosphorus dynamics of pinyon-juniper soils following simulated burning. Soil Science Society of American Journal 52: 271-277.

10. Adams MA, Iser J, Keleher AD, Cheal DC (1994) Nitrogen and phosphorus availability and the role of fire in heathlands at Wilson's promontory. Australian Journal of Botany 42: 269-281.

11. DeRonde C (1990) Impact of prescribed fire on soil propertiescomparison with wildfire effect. In: Fire in ecosystem dynamics. Mediterranean and Northern prespective, pp: 127-136.

12. Stephens SL, Meixner T, Vihnanek RE (2004) Prescribed fire, soils, and stream water chemistry in a watershed in the Lake Tahoe Basin, California. International Journal of Wildland Fire 13: 27-35.

13. Blank RR, Allen F, Young JA (2006) Extractable anions in soils following wildfire in a sagebrush-grass community. Soil Science Society of America Journal 58: 564-570.

14. Giovannini G, Lucchasi S, Giachetti M (1988) Effect of heating on some physical and chemical parameters related to soil aggregation and erodibilty. Soil Science 146: 255-261.

15. Overby ST, Perry HM (1996) Direct effects of prescribed fire on available nitrogen and phosphorus in an Arizona chaparral watershed. Arid Soil Resources and Rehabilitation 10: 347-357.

16. Khanna PK, Raison RJ (1986) Effects of fire intensity on soil solution chemistry under a Eucalyptus pauciflora forest. Australian Journal of Soil Reservation 24: 423-434.

17. Litton CM, Santelices R (2003) Effect of wild-fire on soil physical and chemical properties in a Nothofagus glauca forest, Chile. Revista Chilena Historia Natural 76: 529-542.

18. The Meteorological Service Centre (1999) Periodic meteorological measurements reports. Libyan Meteorological Authority, Shahat, Libya.

19. Al Zunni SA (1977) The forests of Jebel el Akhdar, Libya. Unpublished MSc Thesis, Colorado State University, Colorado, USA.

20. Eldoumi F, Elsaedi O, Zonni E (2010) Study of Aljabal alakhdar's plant cover: Final report, University of Omar Almukhtar, Al-Bieda, Libya: 960 (Arabic document).

21. Hemingway RL (1955) Soil-sampling errors and advisory analyses. Journal of Agricultural Science 46: 1-8.

22. Black CA, Evans DD, White JL, Ensminger LE, Clark FE (1965) Methods of Soil analysis, part (1) and part (2). American Society of Agronomy Inc., publisher Madison, Wisconsin, USA.
23. Allen SE (1989) Chemical analysis of ecological materials. Blackwell Scientific, Oxford, UK.

24. Bethell P, Máté I (1989) The use of soil phosphate analysis in archaeology: a critique. In: Scientific analysis in archaeology Monograph 19: 1-29.

25. Bower CA, Reitemeier RF, Fireman M (1952) Exchangeable cations analysis of saline and alkali soils. Soil Science 73: 251-261.

26. GEFLI (1975) Study of soil and water conservation in Jebel Lakdar. Final report, Ministry of Agriculture and Animal Wealth, Tripoli, Libya: 880.

27. Selkhoz Prom Export U (1980) Soil Studies in the Eastern Zone of the Socialist people Libyan Arab Jamahiria. Secretariat for Agricuttural reclamation and land development, Tripoli, Libya, p: 1280.

28. USDA (Soil Survey Staff) (2001) Soil Taxonomy, A Basic System of Soil classification for Making and Interpreting Soil Surveys. Natural Resources Conservation Service, Agriculture Hand book (436). Washington, DC, USA.

29. Fernandez IAR, Cabaneiro D, Herero M (1997) Organic matter changes immediately after a wildfire in an Atlantic forest soil and comparison with laboratory soil heating. Soil Biology and Biochemistry 29: 1-11.

30. Almendros G, Martin F, Gonzalez-vila FJ (1988) Effects of fire on humic and lipids fractions in a dystric xerochrept in Spain. Geoderma 42: 115-127.

31. Choonsig K, Won KL, Kim ES (1999) Short-term effects of fire on soil properties in Pinus densiflora stands. Forestry Research Institute, Seoul, Korea 4: 23-25.

32. Lee WK, Choi K, Suh S, Kim H (1988) Effect of forest fire on soil properties and vegetation. Forest Research 37: 35-49.

33. Raison RJ, Keith H, Deering L (1990) Effects of fire on the nutrient supplying capacity of forest soils. Forest Research Institue, South Island, New Zealand.

34. Binkley D, Richter D, David MB, Caldwell B (1992) Soil chemistry in a loblolly/longleaf pine forest with interval burning. Ecological Applications 2: 157-164.

35. Baird M, Zabowski D, Everett RL (1999) Wildfire effects on carbon and nitrogen in inland coniferous forests. Plant and Soil 209: 233-243.

36. Dyrness CT, Van Cleve K, Levison JD (1989) The effect of wildfire on soil chemistry in four forest types in interior Alaska. Canadian Journal of Forest Reservation 19: 1389-1396.

37. Rashid GH (1987) Effects of fire on soil carbon and nitrogen in a Mediterranean oak forest of Algeria. Plant and Soil 103: 89-93.

38. Tisdale SL, Beatson WL, Nelson JD (1993) Soil Fertility and Fertilizers. New York, Macmillan.

39. Hungerford RD, Harrington MG, Frandsen WH, Ryan RC, Niehoff JG (1990) Influence of fire on factors that affect site productivity. Symposium on Management and productivity of Western-Montana forest soil, Montana, USA.

40. DeBano LF, Conard CE (1978) The effect of fire on nutrients in a chapparal ecosystem. Ecology 59: 489-497.

41. Duguy B, Rovira P, Gomez R (2007) Land - use history and fire effects on soil fertility in eastern of Spain. Soil Science European Journal 58: 83-91.

42. Foth HD (1984) Fundamental of soil science. 7th edn. John Wiley \& Sons. New York, USA.

43. Tomkins IB, Kellas JD, Tolhurst KG, Oswin DA (1991) Effects of fire intensity on soil chemistry in a eucalypt forest. Australian Journal of Soil Research 29: 25-47. 